\title{
ASSOCIATION BETWEEN TOTAL PHENOL AND FLAVONOID CONTENTS IN ARTOCARPUS HETEROPHYLLUS (JACKFRUIT) BARK AND LEAF EXTRACTS AND LIPOXYGENASE INHIBITION
}

\author{
HAFIDZ MAKARIM ILMI, BERNA ELYA*, ROSITA HANDAYANI
}

Department of Pharmacognosy and Phytochemistry, Faculty of Pharmacy, Universitas Indonesia, Depok, Indonesia. Email: berna.elya@farmasi.ui.ac.id

Received: 19 September 2019, Revised and Accepted: 18 December 2019

\section{ABSTRACT}

Objective: Inflammation is a localized reaction in the tissue in response to injury wherein mediators such as leukotrienes are produced as protective response leukotrienes are synthesized during the metabolism of arachidonic acid by lipoxygenase and they increase capillary permeability and leukocyte adhesion. Artocarpus heterophyllus is used in many medicines due to its natural anti-inflammatory activity. The aim of this study was to use the bark and leaf extracts of $A$. heterophyllus to obtain the most active fraction that could inhibit lipoxygenase and to investigate the total phenol and flavonoid levels in these extracts.

Methods: Barks and leaves were extracted by a multistage reflux method. An in vitro lipoxygenase inhibition assay was performed by measuring the total phenol and flavonoid contents for each fraction.

Results: Ethanol extract was found to be the most active extract in each fraction. $\mathrm{IC}_{50}$ values obtained in the two most active fractions were 31.82 $\mu \mathrm{g} / \mathrm{mL}$ in the ethyl acetate of bark extract and $46.61 \mu \mathrm{g} / \mathrm{mL}$ in the ethyl acetate of leaf extract. This value was higher than that of apigenin standard which has an $\mathrm{IC}_{50}$ value of $2.08 \mu \mathrm{g} / \mathrm{mL}$. The highest phenol content was present in the ethanol leaf extract with $404.903 \mathrm{mg}$ gallic acid equivalent/g extract. Meanwhile, the highest flavonoid content was found in the ethyl acetate of bark extract with $372.362 \mathrm{mg}$ QE/g extract.

Conclusion: The bark and leaf extract tests showed that the increase in the total phenol or flavonoid content was proportional to the increase in the enzyme inhibitory activity.

Keywords: Lipoxygenase, Reflux, Artocarpus heterophyllus, Phenol content, Flavonoid content.

(c) 2020 The Authors. Published by Innovare Academic Sciences Pvt Ltd. This is an open access article under the CC BY license (http://creativecommons. org/licenses/by/4. 0/) DOI: http://dx.doi.org/10.22159/ijap.2020.v12s1.FF055

\section{INTRODUCTION}

Exogenous and endogenous stimuli cause cell injury, thereby causing inflammation of the connective tissue [1]. 5-lipoxygenase (5-LOX) is the main enzymes that play a role in inflammation. 5-LOX oxidizes arachidonic acid to leukotrienes, this reaction leads to the pathogenesis of several diseases such as asthma and rheumatoid arthritis [2,3]. Asthma is one of the most common chronic diseases caused by airway inflammation, and it has been reported in 300 million people worldwide, especially in children [4]. The prevalence of asthma has been increasing in the past 20 years - both in developed and developing countries.

Synthetic drugs in various dosage forms, including oral, aerosol, and liquid preparations, have been developed for treating asthma. Nonsteroidal anti-inflammatory drugs (NSAIDs) and corticosteroids are the most often used drugs for the treatment of inflammation. NSAIDs are known to have a strong effect as an anti-inflammatory agent in asthma and rheumatoid arthritis. However, NSAIDs should be carefully administered because they have many side effects, including digestive disorders such as abdominal pain, stomach ulcers, and anemia due to bleeding in the digestive tract [5].

As an alternative to synthetic drugs, natural ingredients have been used as traditional medicines in Indonesia for long. Artocarpus heterophyllus (jackfruit) is one of the plants in Indonesia that is used as a traditional medicinal ingredient for the treatment of asthma, cough, wounds, itching, and acne [6]. Jackfruit leaves contain alkaloids, saponins, phenols, and flavonoids [7]. However, to the best of our knowledge, the inhibition of 5-LOX by jackfruit leaves/barks has not been elucidated to date. Thus, we performed multistage extractions of $A$. heterophyllus bark and leaf fractions with n-hexane, ethyl acetate, and 96\% ethanol.
We analyzed the association between the total phenol and flavonoid contents in the bark and leaf extracts with the anti-inflammatory activity by performing the lipoxygenase inhibition assay.

\section{METHODS}

Duration of the study

This study was conducted for 5 months from February 2018 to May 2018 in the Phytochemical Research Laboratory, Pharmacognition Laboratory, and Qualitative Analysis Pharmaceutical Chemistry Laboratory, Faculty of Pharmacy, University of Indonesia, Depok.

\begin{abstract}
Equipment
The equipment used in this study was ultraviolet-visible spectrophotometer (PG Instruments Ltd. T80), incubator (Gemmyco), rotary vacuum evaporator (Janke and Kunkel IKA, Buchi Rotavapor R-205), water bath (Imperial IV Water Bath Lab-Line), refrigerator (Sharp), freezers (Sharp), analytical scales (Sartorius 7), digital scales (ACIS, Japan), blender (Kirin), vortex mixers (Wisemix), pH meters (Eutech Instrument, France), condensers, sonicators (WiseClean), 10-10 $\mu \mathrm{L}$ micropipettes (Corning), 100-1000 $\mu \mathrm{L}$ micropipettes (Finnpipette), quartz cuvettes (Merck, Germany), grinding machines, and glassware.
\end{abstract}

\section{Materials}

The materials used in this study were barks and leaves of $A$. heterophyllus (jackfruit) from the city of Depok, and these were analyzed at the Center for Plant Conservation Botanic Gardens-LIPI, Bogor. The other reagents used were apigenin standard (Apigenin analytical standard, SigmaAldrich), water, potassium chloride P, sodium hydroxide, boric acid, linoleic acid, dimethyl sulfoxide, lipoxygenase enzymes (Sigma-Aldrich, USA), nitric acid (Merck, Germany), sodium sulfate anhydrous (Merck, 
Germany), aquades, ethanol (technical), ethyl acetate (technical), and n-hexane (technical).

\section{Extraction}

n-Hexane, ethyl acetate, and ethanol were chosen as the solvents for extraction. A sample-solvent ratio of 1:10 was used for extracting the samples - the amount of this solvent was sufficient to wet the entire surface of the Simplicia with reflux method. After that, the liquid was evaporated until coagulate be extract.

\section{Total phenol content test}

The total phenol content in the extracts was analyzed using the Folin-Ciocalteu method [8]. This method is based on the reduction of a phosphotungstate $\left(\mathrm{WO}_{4}^{2-}\right)$-phosphomolybdate $\left(\mathrm{MoO}_{4}{ }^{2-}\right)$ reagent mixture by the phenolic hydroxyl group of phenol compounds, which results in the formation of a blue color. Color intensity was calculated based on reading the absorbance values in the spectrophotometer [9]. For measuring the total phenol content, gallic acid equivalent (GAE) was used as the reference. The curve was made by plotting gallic acid absorbance against concentrations of $30,40,50,60,70$, and $80 \mu \mathrm{g} / \mathrm{mL}$.

\section{Total flavonoid content test}

The aluminum chloride $\left(\mathrm{AlCl}_{3}\right)$ method was performed for measuring the total flavonoid content. The principle of determining flavonoid content by the $\mathrm{AlCl}_{3}$ method is the complex formation between $\mathrm{AlCl}_{3}$ and keto groups of $\mathrm{C}-4$ atoms and the neighboring hydroxyl groups at $\mathrm{C}-3$ or $\mathrm{C}-5$ atoms. The standard control used for measuring the flavonoid content was quercetin because quercetin is a flavanol (a class of flavonoids) that has keto groups at the $\mathrm{C}-4$ atoms and neighboring hydroxyl groups at C-3 and C-5 atoms (Fig. 1) (Azizah et al., 2014).

$\mathrm{AlCl}_{3}$ addition causes a bathochromic shift toward the visible wavelength, which is indicated by the intense yellow color in the solution. Adding sodium acetate maintains the wavelength in the visible area. Quercetin standards used in this study were made in several concentrations, i.e., $30,40,50,60,70$, and $80 \mu \mathrm{g} / \mathrm{mL}$. The absorbance of each quercetin concentration was used to find the linear regression equation from concentration against absorbance plot. The quercetin standard linear regression equation obtained was $\mathrm{y}=0.0068 \mathrm{x}-0.0079$.

\section{Enzyme inhibition assay}

The enzyme used was 15-lipoxygenase, which was obtained from soybeans. Borate buffer was used to maintain the $\mathrm{pH}$ at 9.0. The concentration of linoleic acid as substrate was optimized for use in the enzyme inhibition assay. The concentrations of the substrate analyzed were in the range of $100-500 \mu \mathrm{M}$. The substrate concentration was selected based on the previous studies, which were performed with $400 \mu \mathrm{M}[10]$.

\section{RESULTS}

From the data below can be seen sample examination, characterization of the leaf samples, entrapment efficiency, lipoxygenase inhibition assay, leaf and bark extract characterization, optimization of linoleic acid uptake, inhibition analyses, total phenol contents, total flavonoid content.

\section{Sample examination}

The extraction results can be seen are listed Table 1. Yield of leaf and bark extracts of Artocarpus heterophyllus (jackfruit).

\section{Characterization of the leaf samples}

Macroscopic from leaf and bark of Artocarpus heterophyllus (jackfruit) are listed Table 2. Then, Microscopic from leaf and bark of Artocarpus heterophyllus (jackfruit) are listed in Figs. 2 and 3.

\section{Entrapment efficiency}

Maraviroc microspheres were characterized for percentage entrapment efficiency. The percentage entrapment efficiency ranged from $50.80 \%$ to $91.43 \%$ (Table 2).

Lipoxygenase inhibition assay

The graph of lipoxygenase inhibition by apigenin is shown in Fig. 4.

Table 1: Yield of leaf and bark extracts of Artocarpus heterophyllus (jackfruit)

\begin{tabular}{lllll}
\hline $\begin{array}{l}\text { Plant } \\
\text { section }\end{array}$ & Solvent & $\begin{array}{l}\text { Extracted Simplicia } \\
\text { weight (g) }\end{array}$ & $\begin{array}{l}\text { Extract } \\
\text { weight (g) }\end{array}$ & $\begin{array}{l}\text { Yield } \\
\text { (\%) }\end{array}$ \\
\hline Leaf & n-hexane ethyl & & 2.23 & 2.23 \\
& acetate & & 2.56 & 2.56 \\
& Ethanol 70\% & & & \\
& & \multirow{2}{*}{100} & 2.13 & 2.13 \\
Bark & Ethanol 70\% & & 2.41 & 2.41 \\
& & & 3.55 & 3.55 \\
& & & 3.02 & 3.02 \\
\hline
\end{tabular}

Table 2: Macroscopic examination results

\begin{tabular}{ll}
\hline Sample & Macroscopic examination results \\
\hline Leaf & $\begin{array}{l}\text { In the form of an oval, round leaf with short leafstalk, } \\
\text { blunt tip, flat-leaf edge, pinnate leaf, and brownish-green }\end{array}$ \\
Bark & $\begin{array}{l}\text { Yellowish-brown, odorless, in the form of cut or slice, } \\
\text { fibrous and hard }\end{array}$ \\
\hline
\end{tabular}

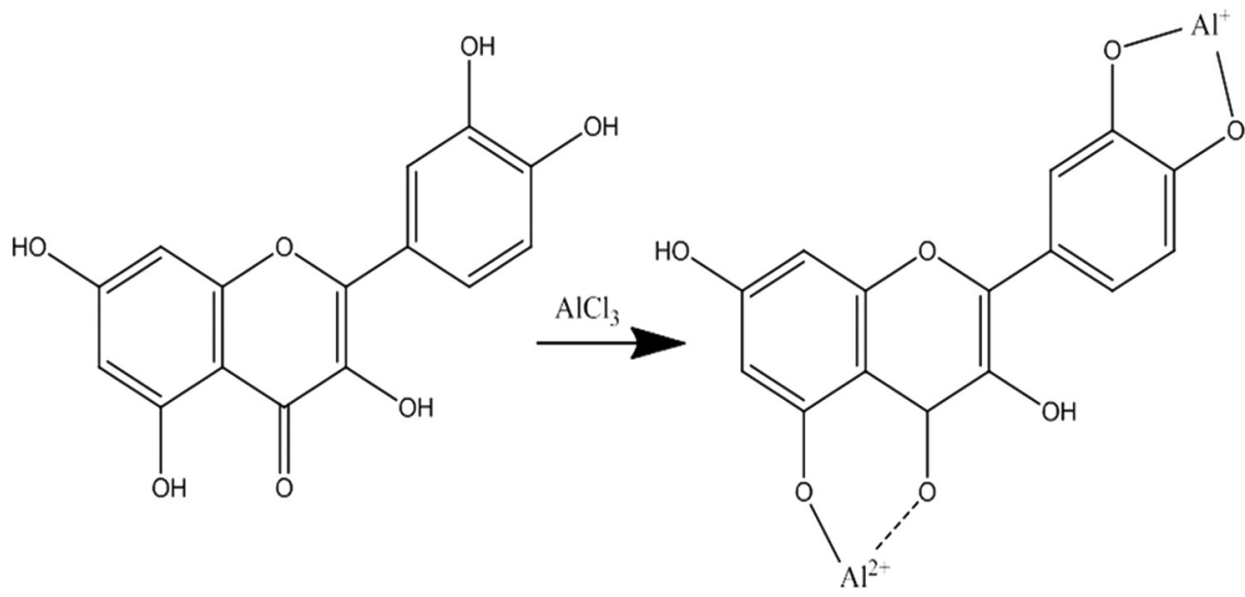

Fig. 1: Complex formation of quercetin-aluminum chloride (Source: Azizah et al., 2014) 


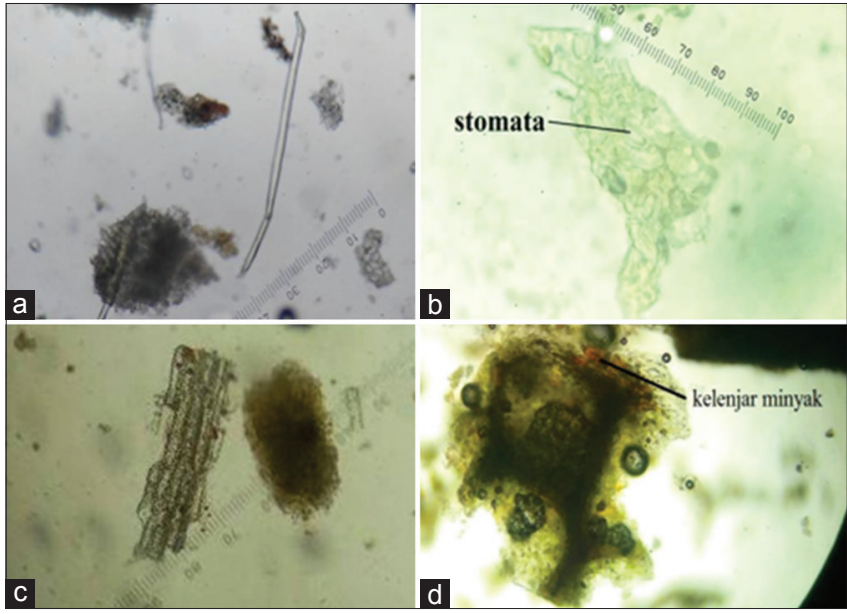

Fig. 2: Microscopic examination of jackfruit leaf Simplicia at $\times 10$; 1-3 hair cells (a); anisocytic stomata type (b); transport with thickened bands resembling ladder (c); oil glands (d)

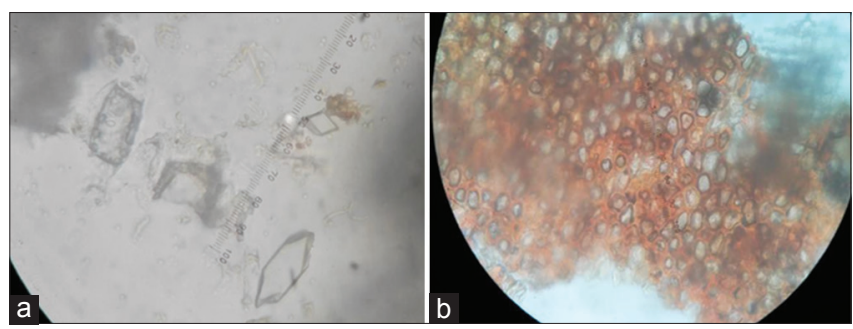

Fig. 3: The results of the microscopic examination of jackfruit bark Simplicia at $\times 40$; cork cells with oil (a); calcium oxalate crystals (b)

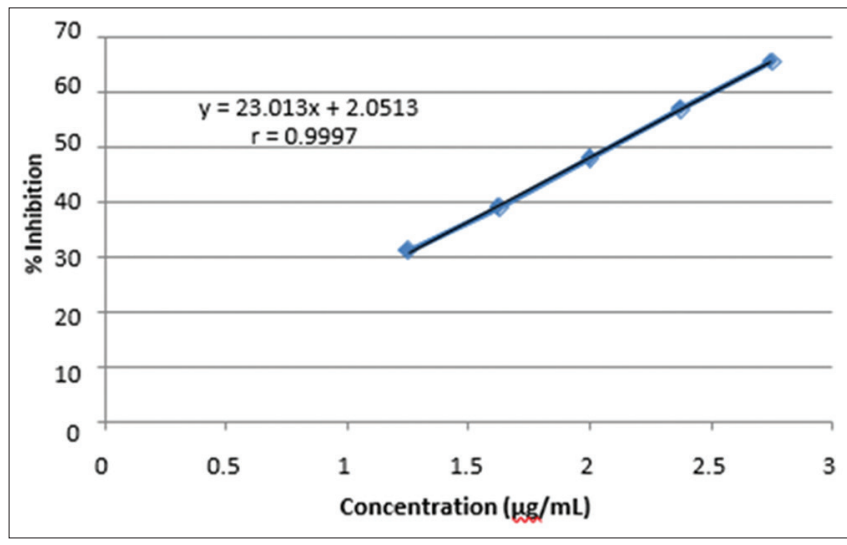

Fig. 4: Graph of lipoxygenase inhibition by apigenin

\section{Leaf and bark extract characterization}

Based on the extraction results, the yield percentage is shown in Table 2.

\section{Optimization of linoleic acid uptake}

Optimization results showed that the uptake of linoleic acid substrate increased with increasing lipoxygenase concentration. The absorption value showed a significant increase up to a substrate concentration of 300 $\mu \mathrm{M}$; then, it became stable, after which there was a slight decrease in the absorption value at the substrate concentration of 400 and $500 \mu \mathrm{M}$. Thus, the optimal substrate concentration was found to be $300 \mu \mathrm{M}$. The results of the overall optimization of the substrate uptake are shown in Table 3.

\section{Inhibition analyses}

As shown in Table 4, the lowest $\mathrm{IC}_{50}$ value was shown by the ethyl acetate bark extract with an $\mathrm{IC}_{50}$ value of $31.82 \mu \mathrm{g} / \mathrm{mL}$ followed by the ethyl acetate leaf fraction with an $\mathrm{IC}_{50}$ value of $46.61 \mu \mathrm{g} / \mathrm{mL}$. Because n-hexane bark and leaf fractions showed $\mathrm{IC}_{50}$ values $>100 \mu \mathrm{g} / \mathrm{mL}$, both fractions were considered to be less potent. This is because the $\mathrm{n}$-hexane fraction is nonpolar with contents such as essential oils and chlorophyll.

\section{Total phenol contents}

As shown in Table 5, the highest total phenol content was observed in the ethanol leaf extract containing $404.903 \mu \mathrm{g} \mathrm{GAE} / \mathrm{mg}$ extract and the ethyl acetate leaf extract containing $177.187 \mu \mathrm{g} \mathrm{GAE} / \mathrm{mg}$ extract. Moreover, the highest total phenol content in the bark was found in the ethyl acetate bark extract containing $189.484 \mu \mathrm{g} \mathrm{GAE} / \mathrm{mg}$ extract.

\section{Total flavonoid content}

As shown in Table 6, the highest average total flavonoid content in the bark was found in the ethyl acetate bark extract with $372.362 \mu \mathrm{g}$ QE/mg extract, while the highest average total flavonoid content in the leaf was found in the ethyl acetate leaf extract with $302.658 \mu \mathrm{g} \mathrm{QE} / \mathrm{mg}$ extract.

\section{DISCUSSION}

To the best of our knowledge, a lipoxygenase inhibition assay with jackfruit bark and leaf extracts has not been reported to date. In this study, a lipoxygenase inhibition assay was performed using fractions from multistage extraction of barks and leaves of jackfruits to investigate the specific properties of the compounds capable of inhibiting lipoxygenase activity based on their polarity. Lipoxygenase was found to be inhibited by jackfruit bark and leaf extracts. The results of our study and those of previous studies show that the polar or semipolar compounds in jackfruit bark and leaf extracts could inhibit the lipoxygenase activity.

In this study, plant extraction was performed by the reflux method, which is a simple extraction method that occurs within a relatively short time. In this method, the equipment is relatively inexpensive and the solvents can be reused [11]. Conventionally, phenolic acids and flavonoid compounds can be extracted by reflux extraction or Soxhlet extraction [12]. n-Hexane, ethyl acetate, and ethanol were chosen for the extraction because each solvent has a different polarity, with the polarity index of n-hexane, ethyl acetate, and ethanol being $0,4.4$, and 5.2, respectively [13]. Therefore, the solvents used in stages from the lowest polarity were n-hexane, followed by ethyl acetate, and finally ethanol.

Lipoxygenase is a group of cytosolic enzymes that catalyze the oxygenation of polyenoic fatty acids to the corresponding lipid hydroperoxides. This enzyme requires a fatty acid substrate with two cis double bonds separated by a methylene group. Arachidonate, which contains multiple double bonds with this configuration, is metabolized into a product that has hydroxyl groups at various positions. Arachidonate is metabolized into hydroperoxy-eicosatetraenoic acid [5], which is further converted into leukotriene-A4 (LTA4) that forms other leukotrienes such as LTB4, LTC4, LTD4, and LTE4. LTB4 is an important compound in the production and release of proinflammatory cytokines [14]. Leukotrienes conjugate with triene compounds formed from eicosanoic acid in leukocytes, mast cells, platelets, and macrophages through the lipoxygenase pathway [15].

In this study, linoleic acid was used as the substrate because it is cheaper and more stable than arachidonic acid. However, the inhibition values of these two substrates are comparable. 15-lipoxygenase was maintained stably in borate buffer at the optimum $\mathrm{pH}$ of 9.0. The resulting product formed a conjugated double bond, which increased absorbance at $234 \mathrm{~nm}$. The increase in absorbance was used for the calculation of the number of products produced so that the inhibition value can be known [10]. During the optimization of linoleic acid uptake, we observed that the uptake began to decrease at a concentration of 400 $\mu \mathrm{M}$ because the active sites of the enzyme were filled with the linoleic acid substrate so that no enzyme was free to form the enzyme-substrate complex. Therefore, the addition of more substrate did not increase the reaction rate or have any significant effect on the measured uptake [15]. 
Table 3: Data optimization of linoleic acid substrate at $\lambda_{234}$

\begin{tabular}{|c|c|c|c|c|c|c|c|}
\hline $\begin{array}{l}\text { Initial substrate } \\
\text { concentration }\end{array}$ & Uptake sample & Control sample & S-KS & Average & SD & Cv (\%) & $\begin{array}{l}\text { Initial concentration of } \\
\text { optimum substrate }\end{array}$ \\
\hline$(\mu \mathrm{M})$ & (S) & (KS) & & S-KS & & & \\
\hline \multirow[t]{3}{*}{100} & 0.887 & 0.506 & 0.381 & 0.377 & 0.003 & 0.81 & \\
\hline & 0.889 & 0.514 & 0.375 & & & & \\
\hline & 0.832 & 0.455 & 0.377 & & & & \\
\hline \multirow[t]{3}{*}{200} & 0.96 & 0.534 & 0.426 & 0.434 & 0.007 & 1.61 & \\
\hline & 0.976 & 0.539 & 0.437 & & & & \\
\hline & 0.975 & 0.536 & 0.439 & & & & \\
\hline \multirow[t]{3}{*}{300} & 1.035 & 0.538 & 0.497 & 0.494 & 0.004 & 0.88 & 300 \\
\hline & 1.011 & 0.522 & 0.489 & & & & \\
\hline & 1.037 & 0.541 & 0.496 & & & & \\
\hline \multirow[t]{3}{*}{400} & 0.992 & 0.505 & 0.487 & 0.489 & 0.002 & 0.41 & \\
\hline & 1.094 & 0.603 & 0.491 & & & & \\
\hline & 1.032 & 0.543 & 0.489 & & & & \\
\hline \multirow[t]{3}{*}{500} & 1.02 & 0.545 & 0.475 & 0.474 & 0.003 & 0.74 & \\
\hline & 0.981 & 0.51 & 0.471 & & & & \\
\hline & 1.014 & 0.536 & 0.478 & & & & \\
\hline
\end{tabular}

Table 4: $\mathrm{IC}_{50}$ values of leaf extracts (n-hexane, ethyl acetate, and ethanol) and bark (ethanol)

\begin{tabular}{ll}
\hline Extract & IC $_{\mathbf{5 0}}(\boldsymbol{\mu g} / \mathbf{m L})$ \\
\hline Ethanol leaf & 75.27 \\
Ethyl acetate leaf & 46.61 \\
n-Hexane leaf & 152.27 \\
Ethanol bark & 75.87 \\
Ethyl acetate bark & 31.82 \\
n-Hexane bark & 141.49 \\
\hline
\end{tabular}

Table 5: Average total phenol content

\begin{tabular}{ll}
\hline Extract & Average total phenol ( $\boldsymbol{\mu g}$ GAE/mg) \\
\hline Ethanol leaf & 404.930 \\
Ethyl acetate leaf & 177.187 \\
n-Hexane leaf & 78.327 \\
Ethanol bark & 152.192 \\
Ethyl acetate bark & 189.484 \\
n-Hexane bark & 31.339 \\
\hline GAE: Gallic acid equivalent &
\end{tabular}

Table 6: Average total flavonoid content

\begin{tabular}{ll}
\hline Extract & Average total flavonoid $(\boldsymbol{\mu g Q E} / \mathbf{m g})$ \\
\hline Ethanol leaf & 49.350 \\
Ethyl acetate leaf & 302.658 \\
n-Hexane leaf & 76.308 \\
Ethanol bark & 45.308 \\
Ethyl acetate bark & 372.36 \\
n-Hexane bark & 87.807 \\
\hline
\end{tabular}

We performed the lipoxygenase inhibition assay with apigenin to assess if this method could be used as well as to compare the percentage inhibition and $\mathrm{IC}_{50}$ values between the samples and the positive controls. In the standard apigenin assay, a standard control test was also used, which was needed to correct the results of the standard uptake if the enzyme still showed activity after being stopped or if there were other compounds that provide absorption at the wavelength of the test solution measurement. Testing of blank solution and blank control facilitates the determination of the enzyme activity without inhibition. The test results showed that the $\mathrm{IC}_{50}$ value of apigenin for inhibiting lipoxygenase was $2.08 \mu \mathrm{g} / \mathrm{mL}$. The previous studies showed that the $\mathrm{IC}_{50}$ value of apigenin was $2.03 \mu \mathrm{g} / \mathrm{mL}$ [10]. This difference may be attributed to the measurement conditions such as temperature and the use of different instruments.
At concentrations below $100 \mu \mathrm{g} / \mathrm{mL}$, four extracts from jackfruit barks and leaves showed more than 50\% inhibition activity in the lipoxygenase inhibition assay. Phenolic compounds such as flavonoids have been reported to inhibit lipoxygenase [16]. In the total phenol content assay test, gallic acid was chosen as the standard due to the availability of gallic acid as a stable and pure substance; moreover, gallic acid is relatively cheaper than other standard compounds [17]. The results of the total phenol content assay showed that there was an association between the increased total phenol content in the extract and the increase in the ability to inhibit enzyme activity, as shown by the jackfruit leaf extract. High levels of phenols also influence the antiinflammatory activity, which was shown by the decrease in the $\mathrm{IC}_{50}$ values [7].

Several studies have shown that flavonoid compounds can inhibit lipoxygenase activity $[18,19]$. Some flavonoid compounds, including astragalin, quercitrin, luteolin, amentoflavone, lonicerin, rhoifolin, and genistein, can inhibit lipoxygenase activity with the highest percentage inhibition shown by luteolin with an $\mathrm{IC}_{50}$ value of $5 \mu \mathrm{g} / \mathrm{mL}$.

Our study shows that an increase in the total phenol and flavonoid content is proportional to the increase in the enzyme inhibitory activity. Thus, barks and leaves of jackfruits extracted with ethanol or ethyl acetate can maximally inhibit lipoxygenase activity, thereby making them useful to be considered in the development of anti-inflammatory drugs.

\section{CONCLUSION}

In future studies, variations in the concentrations for comparing the $\mathrm{IC}_{50}$ values should be made the same. Further fractionation and isolation processes need to be performed on the extract with the highest inhibitory activity to identify the specific active compounds that are responsible for the inhibitory activity.

\section{CONFLICTS OF INTEREST}

All authors have none to declare.

\section{REFERENCES}

1. Hamik A, Lin Z, Kumar A, Balcells M, Sinha S, Katz J, et al. Kruppel-like factor 4 regulates endothelial inflammation. J Biol Chem 2007;282:13769-79

2. Luo M, Lee S, Brock TG. Leukotriene synthesis by epithelial cells. Histol Histopathol 2003;18:587-95.

3. Krishna CK, Gopalakrishnan VK, Hagos Z, Govinda RD. Mesuaferrin a-bioactive flavonoid isolated from the bark of Mesua ferrea L. Against phospholipase $\mathrm{A}_{2}$, cyclooxygenase and lipoxygenase: $\mathrm{An}$ in vitro, in vivo and in silico approach. Int J Pharm Pharm Sci 2018;10:102-6. 
4. World Health Organization. Asthma. Geneva: World Health Organization Press; 2005.

5. Goodman and Gilman. Dasar Farmakologi Terapi. Hardman JG, Limbird LE, editors. Alfred Goodman Gilman, Diterjemahkan Oleh Tim Alih Bahasa Sekolah Farmasi ITB. Jakarta: Penerbit Buku Kedokteran EGC; 2012.

6. Elevitch CR, Dan Manner HI. Artocarpus heterophyllus (Jackfruit). Species Profiles for Pacific Island Argoforestry; 2006. Available from: http://www.agroforestry.net/tti/a.heterophyllus-jackfruit.pdf. [Last accessed on 2011 Apr 03].

7. Wang XX, Di XX, Shen T, Wand SQ, Wang XN. New phenolic compounds from the leaf of Artocarpus heterophyllus. Sci Direct 2017;28:37-40.

8. Singleton VL, Rossi JA. Colorimetry of total phenolics with phosphomolybdic- phosphotungstic acid reagents. Am J Enol Vitic $1965 ; 16: 144-58$

9. Vermerris W, Nicholson R. Phenolic Compound Biochemistry. Dordrecht: Springer; 2008.

10. Nabilah EB, Djajadisastra J. Lipoxygenase inhibitory assay of Averrhoa carambola L. Leaf extract. Int J ChemTech Res 2017;10:342-7.

11. Khoddami A, Wilkes MA, Roberts TH. Techniques for analysis of plant phenolic compounds. Molecules 2013;18:2328-75.

12. Ghasemzadeh A, Ghasemzadeh N. Flavonoids and phenolic acids: Role and biochemical activity in plants and human. J Med Plants Res
2011;5:6697-703.

13. Abarca-Vargas R, Peña Malacara CF, Petricevich VL. Characterization of chemical compounds with antioxidant and cytotoxic activities in Bougainvillea x buttiana holttum and standl, (var. Rose) extracts. Antioxidants (Basel) 2016;5:E45.

14. Dobrian AD, Lieb DC, Cole BK, Taylor-Fishwick DA, Chakrabarti SK, Nadler JL. Functional and pathological roles of the 12- and 15-lipoxygenases. Prog Lipid Res 2011;50:115-31.

15. Murray RK, Granner DK, Rodwell VW. In: Pendit BU, editor. Harper's Biochemistry. 27th ed. Jakarta: Penerbit Buku Kedokteran EGC; 2006.

16. Doiron J, Boudreau LH, Picot N, Villebonet B, Surette ME, Touaibia M. Synthesis and 5-lipoxygenase inhibitory activity of new cinnamoyl and caffeoyl clusters. Bioorg Med Chem Lett 2009;19:1118-21.

17. Waterhouse A. Determination of total phenolics. Current Protocols in Food Analytical Chemistry. Hoboken: John Wiley and Sons, Inc.; 2003.

18. Proença C, Freitas M, Ribeiro D, Oliveira EF, Sousa JL, Tomé SM, et al. $\alpha$-Glucosidase inhibition by flavonoids: An in vitro and in silico structure-activity relationship study. J Enzyme Inhib Med Chem 2017;32:1216-28.

19. Hubert BJ, Adama H, Moussa C, Ahmed CY, Martin K, Germaine NO. Anti-inflammatory activities of fruit and leaves extract of Lannea microcarpa England K. Kraus (Anacardiaceae). Int J Pharm Pharm Sci 2015;7:177-82. 